\title{
Efforts to Achieve Environmental Sustainability through Ecotourism
}

\author{
Yerik Afrianto Singgalen ${ }^{1 *}$, Gatot Sasongko², Pamerdi Giri Wiloso ${ }^{2}$ \\ ${ }^{1}$ Politeknik Perdamaian Halmahera, North Halmahera, North Maluku, Indonesia \\ ${ }^{2}$ Satya Wacana Christian University, Salatiga, Central Java, Indonesia
}

\begin{abstract}
This paper will discuss specifically the effort of Kupa-Kupa Beach Cottage and Meti Beach Cottage managers to achieve environmental sustainability through the concept of ecotourism. Furthermore, private sector involvement and mixed marketing strategy will be discussed to describe how community empowerment and local community support as an essential factor in regional tourism development, especially in North Halmahera District. The research method used is qualitative with case study approach. This paper shows that the private sector tends to adopt a community-based ecotourism concept to achieve environmental sustainability and tourism sustainability itself. The government will act as a stimulus and catalyst that is synergistic with the needs of the private sector to provide tourism facilities according to tourists' preference. Kupa-Kupa Beach Cottage and Meti Beach Cottage managers seek to provide employment for local communities as part of a marketing strategy so that they are mutually beneficial.
\end{abstract}

Keywords: Community empowerment, ecotourism, environmental sustainability, mixed marketing strategy, private sector involvement.

\section{INTRODUCTION}

Tourism is one of the priority sectors of national development in Indonesia since 2015. The contribution of the tourism sector for the economy of Indonesia is the availability of employment opportunities as solutions to problems of unemployment and increase income per capita to prosper as a solution and tackle the problem of poverty in Indonesia [1-4]. Tourism also provides social benefits with a reduction of the potential economic consequences of the conflict as well as strengthen social values and local cultures $[5,6]$. Tourism also provides benefits to the environment through the concept of Ecotourism [7]. This indicates that tourism is capable of delivering the benefits of social, economic and environmental issues, although some researchers showed a negative impact from tourism $[8,9]$.

Some researchers previously showed that the implementation of the concept of ecotourism by involving local communities is a strategy to achieve sustainable tourism [10,11,12]. Nevertheless, the study of private sector participation in the development of ecotourism still shows the gap in the detail according to each context of the regions, especially in developing countries [13]. This paper will outline the efforts of the private sector in achieving sustainable tourism through the concept of ecotourism.

\footnotetext{
* Correspondence Address:

Yerik Afrianto Singgalen

E-mail : singgalen.yerik@gmail.com

Address : Politeknik Perdamaian Halmahera, Wari Ino, Tobelo, North Halmahera, North Maluku, 97762
}

Ecotourism development concept into environmentally friendly tourism and provide economic and social benefits [14]. Further, local people became an important actor in the process of implementation of the approach to ecotourism [15]. In addition, the Government is acting as a catalyst or stimulus in the development of tourism to increase the participation of local communities. Government and entrepreneurs in tourism also have a very important role in pushing the acceleration of development through ecotourism approach [16]. This indicates that private and public sector or local community have an essential role in achieving the success of the development of tourism, thus the partnership between stakeholders becomes a very essential aspect in achieving the sustainability of tourism itself.

Research on ecotourism development implementation tends to emphasize the participation of the community as well as the benefits of economic, social and environmental [17-21]. Nevertheless, different contexts of region and community show the different level of participation. According to the case of North Halmahera Regency as a post-conflict area which is located in the border area of Indonesia and the Philippines showed the shape and different levels of participation [4]. The community so actively participate in various meetings, coaching, and counseling, as well as maintaining environment 
security. Even so, the scope of his research is limited in Tagalaya, Kumo and Kakara Island. In another hand, the different case showed that the community as a fisherman in the North Kao region still use bombs in the process of catching fish so damaging coral reefs [22]. Thus it can be noted that each context show the different conditions.

This paper will discuss specifically the effort of Kupa-Kupa Beach Cottage and Meti Beach Cottage managers to achieve environmental sustainability through the concept of ecotourism. Furthermore, private sector involvement and mixed marketing strategy will be discussed to describe how community empowerment and local community support as an essential factor in regional tourism development, especially in North Halmahera District.

\section{MATERIALS AND METHOD}

The research method used is qualitative and case study approach. This study used in-depth interview technique, observation and document study. The informants involved in this research are the manager of Kupa-Kupa Beach Cottage ( $O$ and $L)$ and Meti Beach Cottage ( $A$ and $M)$. Interviews also conducted with the key informants of the local community in Kupa-Kupa Village (KD) and Meti Village (RT) and Tobelo Timur Sub-District Head (RJ). The discussions and interviews with the sea transport service provider from Mawea Village to Meti Island have agreed with the researchers not to publicize the identity of the informants. In addition, observations were conducted at the site of Kupa-Kupa beach Cottage and Meti Beach Cottage. The study of the intended document is the searching of information through the internet to sharpen the analysis. Data validation process use triangulation technique to obtain credible information. This study focuses on the efforts of the private sector to achieve environmental sustainability through ecotourism approaches.

\section{Data Collections}

The data retrieval process is done using an indepth interview technique. In the early stages, researchers only come as tourists to observe the business environment of cottages on Kupa-Kupa beach and Meti Island. On the first visit, the researcher chatted with local people who sell around the tourist attraction while discussing related to the presence of cottage entrepreneurs. Researchers are wondering about the economic benefits derives from tourism activities to society.

Furthermore, researchers visited Kupa-Kupa Beach Cottage and Meti Beach Cottage entrepreneur to ask questions related to business management. After establishing a good relationship with the entrepreneur, the researcher delivers the intent and purpose of conducting the research so that it takes time for in-depth interviews. The in-depth interview process can be done when the entrepreneur is not busy serving the guests, besides there is a different context between Kupa-Kupa Beach Cottage and Meti Beach Cottage.

Kupa-Kupa Beach Cottage has been started from 2006 while Meti Beach Cottage has only been pioneered since 2016. Nevertheless, both are struggling to keep the environment around the cottages from the activities of the people as fishermen who catch fish using bombs. Considering this, researchers focus on strategies or efforts to achieve environmental sustainability through service optimization in each business. Researchers make observations in the business environment to reconcile information obtained from interviews.

In addition, researchers also traced information through social media and online news to ensure the real conditions in Kupa-Kupa Bay and Meti Island. Thus, this study also uses observation techniques and document studies to obtain credible information. Although the focus is on entrepreneurs, researchers also conduct discussions with local people who are entrepreneurial in tourism objects as well as communities who work as a provider of local sea transportation services. Thus the process of this research can be completed.

\section{RESULTS AND DISCUSSION Ecotourism Development}

Revitalization under Reconciliation is a portrait of the social, economic and environmental issues in North Halmahera Regency. In 1999-2000 in the town of Tobelo, North Halmahera Regency never happened due to conflict issues that influence the relationship of Sarah believers [23]. The implications of these conflicts affect the life of the community in sustaining life, related to livelihood. In situations of conflict, stunted economy activity so that an attempt to satisfy daily needs done in the traditional way as well as catching fish for consumption. In the context of Kupa-Kupa Village and Meti island, the coral reefs around have been damaged by fishing activity using a homemade bomb. This indicates the existence of a threat to environmental sustainability that also affects the tourism sector as defamation.

The local government cooperates with the police in collaboration to observe the water 
environment conditions in Kupa-Kupa Bay and Meti Island by establishing a policy to ban fishing activities using fish bombs and to give strict sanctions to those who violate the regulation. In addition to negatively impacting the sustainability of the underwater natural environment, such activity is also harmful to individuals.

Based on Fatimah Yamin's information in Kompas media on $7^{\text {th }}$ January in 2016 that one of the Kupa-Kupa villagers on behalf of Rulan Djakolo (39th) was found dead with both arms broke off in a boat due to a fish bomb exploding in hand. Meanwhile, a fellow victim named HR (35th) also suffered injuries to the head and chest. According to $A R$ as headman of Kupa-Kupa village, the incident was known when he heard the explosion.

Meanwhile, the representation of North Halmahera Police, YR on Thursday the 7th day of January 2016 in cooperation with the Department of Marine and Fisheries investigated the case to find out the origin of the materials used in making the homemade bomb. This shows the efforts of various stakeholders to protect the environment by preventing the development of fishing activities using homemade bombs that negatively impact the environmental sustainability and image of regional tourism.

Fishing using homemade bombs is not only happening in North Halmahera, but also in other regions such as Sulawesi and Southeast Maluku. Arakan and Wawontulap villages as a part of Bunaken National Park, indicating the presence of fishermen who often catch fish with fish bombs [24]. Further explanation shows that bomb fishing started in the Permesta war in 1967-1959 when troops from the center were brought to North Sulawesi to feed troops in large numbers, so the army cooks invited some fishermen to catch fish using hand grenades.

In 1979, when Indonesia was safe, fishermen attempted to assemble their own bombs by cutting out unused bullets for gunpowder, inserted into bottles to bomb. The impact of the use of bombs on coral reefs is $25 \%$ of coral damage, so fishermen have to look to more remote areas. Meanwhile, the damage to coral reef ecosystems in Small Kei Sub-district, Southeast Maluku Regency consist of natural factors and human factors [25]. Further explanation shows that damage to the coral reef ecosystem is more dominant in human activities ie fishing using handmade bombs, nets, and coral retrieval for building materials.

In the other hand, the arbitrary fishing behavior in the use of illicit tools or materials is caused by poverty [26]. The factors that influence the fishing behavior associated with poverty: institutional harm to small fishermen; programs that do not favor small fishermen; an afterlife oriented worldview; resource constraints; incompatibility of fishing gear; low investment; debt-bonded; extravagant behavior; limited seasons of arrest; damage to ecosystems; arrest of catch territory; weak law enforcement; competition to outperform other fishermen. This shows the factors that influence fishing behavior by fishermen.

In the context of the Kupa-Kupa Bay and Meti Island, coral reefs are the main attraction. This means that damage to coral reef ecosystems is a threat to the sustainability of the tourism sector. Local Government of North Halmahera determining the direction of policies and development strategies of tourism-based ecomarine, heritage and culture. Ecotourism is becoming one of the concepts of development of tourism in North Halmahera Regency so that elements of the conservation, the welfare of local communities and the responsible travel (responsible tourism) is very essential in the development of tourist attractions.

As for, the principles are taken into consideration in the development of tourism of North Halmahera Regency is as follows: minimalize negative impact on the environment; increasing concern for the environment and culture; provide a positive experience for tourists visiting or host; provide financial benefits for local people. Recently, development strategies undertaken is the development of the natural attractions that paying attention to the sustainability of flora and fauna, the development of tourism facilities by considering their impact on the environment, as well as involving the community to actively participate in the activities of the tour. Thus it can be noted that the approach to ecotourism is strategies to achieve sustainable tourism through community-based tourism development.

Meti island is one of the leading tourist attractions in North Halmahera Regency. In 2015, there was an issue arisen from land use controversies that caused a number of ancillary facilities for tourism are not well-maintained to damaged [4,27]. However, the management of the tourist destination is getting better after being developed by the private sector. Meti island is currently the most popular tourist destination for foreign tourists as shown in Figure 1. 


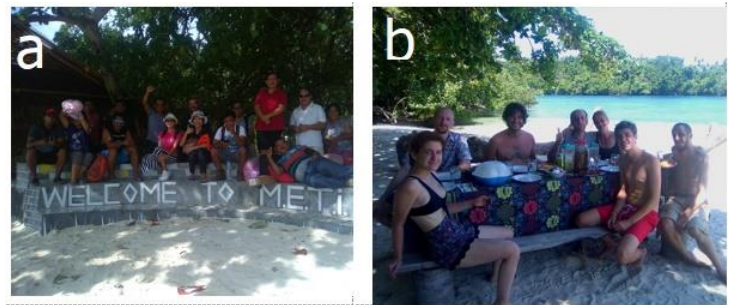

Figure 1. Meti Beach Cottage, in a) Local Visitors, b) Foreign Tourist (Source : PulauMeti, 2018)

Figure 1 shows that the island of Meti has tourism potential that can be developed so as to deliver the benefits of economic, social and environmental. In the year 2016, CV. Meti Bali Beach, establish communication with the landlord then hired a land use within the period agreed upon together. Meti Beach Cottage Manager develop attractions with themes of eco-friendly tourism. It can be seen from the building of cottages which uses eco-friendly materials in the form of bamboo and the roof of the local community which is also used in building settlements. In addition, the neighborhood cottage also cleaned and arranged well-giving rise to the impression is convenient for tourists who visit. As for the form of cottages that have been built can be seen in Figure 2 below.

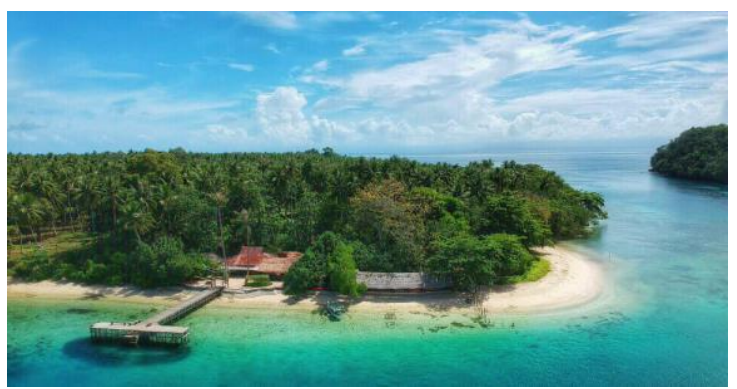

Figure 2. Meti Beach Cottage (Source: Observation, 2018)

Figure 2 is a portrait of Meti Beach Cottages recorded using a drone. The concept of ecotourism adopted by Meti Beach Cottages entrepreneurs is inseparable from the characteristics of local culture. In addition, to create a comfortable and safe atmosphere and achieve environmental sustainability, businessman Meti Beach Cottage in cooperation with the Village Government and the people of Meti who work as a provider of sea transportation (ketinting) to synergize in determining the tariffs of affordable transportation services for tourists.

Furthermore, the matters discussed in the form of cooperation with the village government and the local community are the prohibition to catch fish using fish bombs, the rules for not catching fish around the cottages, the rules not to dispose of plastic waste in the waters of Meti Island as well as in the cottage environment as well regulation not to consume liquor and drugs in the cottage environment. Thus it can be seen that the private sector has a very essential role in achieving environmental sustainability through ecotourism. In the context of Kupa-kupa Beach tourism object, Kupa-Kupa Beach Cottage entrepreneurs also adopt the concept of ecotourism. It can be seen from the building materials used and the beautiful environmental management, as in Figure 3 below.

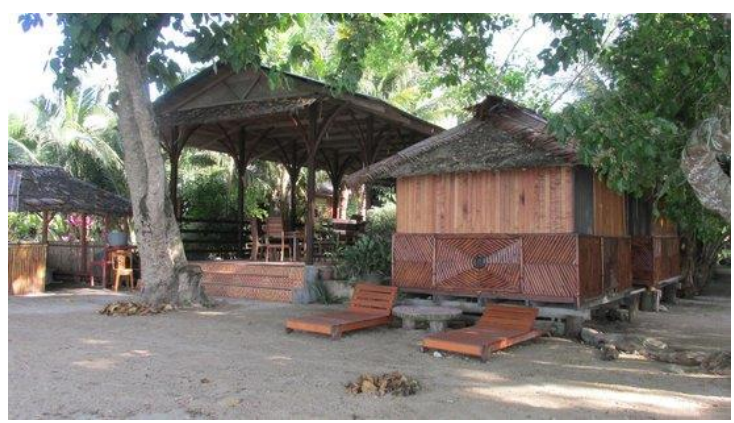

Figure 3. Kupa Kupa-Beach Cottage (Source: Personal Documentation, 2018)

Figure 4 shows that the Kupa-Kupa Beach Cottage businessman adopts the concept of ecotourism through the building materials used. Kupa-Kupa Beach Cottage is also a stimulus for the development of tourism business on Kupa-Kupa beach. In addition, Kupa-Kupa Beach Cottage entrepreneurs maintain cleanliness and arranging the environment around the cottage so as to create a sense of security and comfort for tourists who visit. Entrepreneur Kupa-Kupa Beach Cottage also employs local communities in cottage business management, providing business locations for local communities. This indicates that the presence of Kupa-Kupa Beach Cottage not only provides ecological benefits but provides economic and social benefits for local communities, as in Figure 4 below.

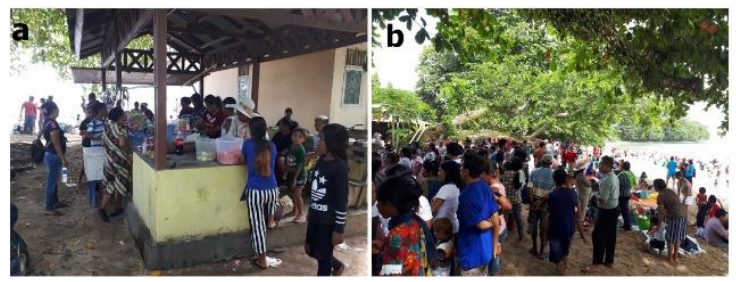

Figure 4. Kupa-Kupa Beach Cottage, in a) Community Empowerment, b) Local Visitor (Source: Personal Documentation, 2018)

Figure 4 shows that the existence of the private sector in regional tourism development is very beneficial. Therefore, a collaboration 
between the government, local community and private sector is needed to achieve sustainable tourism development by adopting ecotourism principles. In the context of North Halmahera Tourism, the main problem occurred is the land disputes which result in vandalism [4]. Therefore, the concrete step to achieving sustainability in tourism is to involve the private sector and provide space for creativity in accordance with their respective business development strategies without ignoring socio-cultural, economic and environmental conditions.

\section{Marketing Strategy of Kupa-Kupa Beach Cottage and Meti Beach Cottage}

Marketing strategies are always set based on the perceptions of consumers. In this context, the perception of local tourists and the foreign tourist is very essential to determine the right tourism products. On the other hand, perceptions of local communities can be known through communication in the form of discussions as well as indepth interviews with classifying communities that benefit from the activity of the business community who are not cottages and benefit business activity of the cottage [28].

The perception of Kupa-Kupa Beach Cottage and Meti Beach Cottage entrepreneurs is inseparable from the marketing strategy. It is related to the product, location selection, price, promotion, process, physical environment condition and participant specified by the entrepreneur. Generally, entrepreneurs are oriented to economic advantage, where the desire to gain maximum profit is more dominant. Nevertheless, the subjectivity of the entrepreneur is able to show different things where the orientation of entrepreneurship based on social goals to achieve the welfare of the community [29]. Thus, it can be seen that the marketing strategy also reflects the orientation of entrepreneurs. Meanwhile, marketing strategy Kupa-Kupa Beach Cottage and Meti Beach Cottage can be seen in Table 1.

Table 1 shows the existence of differences and similarities in marketing strategies between entrepreneurs Kupa Kupa-Beach Cottage with Meti Beach Cottage. Marketing strategy of Kupa Kupa Beach Cottage in terms of product, location, price, promotion, process, environmental and physical conditions participants have run from the year 2006, the entrepreneur Kupa Kupa Beach Cottage very responsive and Adaptive on the development of information technology so that innovation and diversification of products and services always adjust the demand of tourists.

Table 1. Mixed Marketing Strategy of Kupa-Kupa Beach Cottage and Meti Beach Cottage

\begin{tabular}{|c|c|c|}
\hline $\begin{array}{l}\text { Marketing Mix } \\
\text { Strategy }\end{array}$ & $\begin{array}{l}\text { Kupa-Kupa Beach } \\
\text { Cottage }\end{array}$ & $\begin{array}{l}\text { Meti Beach } \\
\text { Cottage }\end{array}$ \\
\hline Product & Services Lodging & Services Lodging \\
\hline Place & Kupa-Kupa Bay & Meti Island \\
\hline Price & $\begin{array}{l}\text { IDR. 250.000- } \\
\text { IDR.450.000 }\end{array}$ & $\begin{array}{l}\text { IDR.5.850.000- } \\
\text { IDR.6.950.000 }\end{array}$ \\
\hline Promotion & $\begin{array}{l}\text { Word of Mouth, } \\
\text { Social Media, } \\
\text { Trip-Advisor, } \\
\text { Youtube, Blog, } \\
\text { Newspaper. }\end{array}$ & $\begin{array}{l}\text { Word of Mouth \& } \\
\text { Social Media, } \\
\text { Youtube, Blog, } \\
\text { Newspaper. }\end{array}$ \\
\hline Process & $\begin{array}{l}\text { Check-in can be } \\
\text { accessed online } \\
\text { or via telephone } \\
\text { and email, there } \\
\text { is a pick-up } \\
\text { service, hotel } \\
\text { standard services. }\end{array}$ & $\begin{array}{l}\text { Check-in can be } \\
\text { accessed online } \\
\text { or via telephone } \\
\text { and email, there } \\
\text { is a pick-up } \\
\text { service, hotel } \\
\text { standard services. }\end{array}$ \\
\hline $\begin{array}{c}\text { Phisical } \\
\text { Environment }\end{array}$ & $\begin{array}{l}\text { Cottage } \\
\text { surroundings are } \\
\text { always cleaned as } \\
\text { well as the waters } \\
\text { surrounding } \\
\text { always } \\
\text { supervised } \\
\end{array}$ & $\begin{array}{l}\text { Cottage } \\
\text { surroundings are } \\
\text { always cleaned as } \\
\text { well as the waters } \\
\text { surrounding } \\
\text { always } \\
\text { supervised }\end{array}$ \\
\hline son & $\begin{array}{l}\text { Local Community } \\
\text { Empowerment }\end{array}$ & $\begin{array}{l}\text { Local Community } \\
\text { Empowerment }\end{array}$ \\
\hline
\end{tabular}

Different case with Meti entrepreneur Bali Beach which recently pioneered the effort in the year 2016 and is still in the stage of adaptation with the social environment of local communities. However, both attempts to maintain environmental sustainability and involve local communities in the management of business thereby providing economic benefits i.e. job opportunities and increase per capita income. Consider the efforts of Meti Beach Cottage that recently pioneered in the year 2017, the description of the related marketing strategies more dominant on the Kupa Kupa-Beach Cottage.

Kupa-Kupa Beach Cottage set the price according to the room service and a number room reserved around IDR 250,000 to IDR 450,000 PerDay, depending on facilities and room types. While Meti Beach Cottage sells tourism products in packages with prices around IDR. 5.850.000 to IDR 6.950.000. In addition, the promotion is done gradually starting from the mouth (word of mouth) until the digital campaign products business through social media as well as other online applications like trip-advisor and youtube. Word of mouth promotion results i.e. impression travelers in trip-advisor online applications, as well as personal blogs, are written by travelers in 
the form of impression and experience stay at Kupa Kupa-Beach Cottage.

The production process in this process of service provision can be done manually or use an online trip-advisor. The physical condition of the environment surrounding the business place become excellent products so that environmental sustainability is always maintained well. It can be seen from the various types of plants are maintained so as to make environmental businesses exquisite. Assessment of services in the Kupa Kupa-Beach Cottage can be searched online via the application of trip-advisor is used for promotion of the business as well as tourist blog tells about the experience of tourists during their stay in the Kupa Kupa-Beach Cottage. Even so, the assessment is a subjective opinion. As for the comment, in the application of trip-advisor on Kupa Kupa-Beach Cottages and can be seen in Table 2 below.

Table 2 shows the various impressions and commentaries as members of a trip-advisor on Kupa-Kupa Beach Cottage. Tourists who give an average rating of one person, while there are six tourists who provide excellent ratings and four tourists who provide outstanding ratings. The most dominant tourists comment on the physical condition of the environment, room facilities, service, and employee friendliness. In addition, only three tourists comment on product prices, as for comments about the price of the product is not a negative comment but a positive comment where the price of the product in accordance with the products and services provided. Thus it can be seen that the perception of tourists visiting KupaKupa Beach Cottage has a positive impression. This indicates that the existence of the private sector through cottages business are able to improve tourism destination brand.

In the year 2017, Meti Beach Cottage pioneering efforts with a different strategy. At the stage of pioneering, the entrepreneur seeks to synergize with local communities, learn to understand the local culture. In addition, Meti Beach Cottage manager adopted the concept of ecotourism as guidelines in the development of businesses that are able to provide the benefits of economic, social and environmental. It can be seen from the results of the interview along with A \& $M$, as follows:

Table 2. Impressions and comments of travellers about the Kupa Kupa-Beach Cottage (Trip-Advisor Member)

\begin{tabular}{|c|c|c|c|c|c|c|c|c|}
\hline \multirow{2}{*}{$\begin{array}{c}\text { Name Account Trip } \\
\text { Advisor }\end{array}$} & \multirow{2}{*}{$\begin{array}{l}\text { Traveler } \\
\text { Rating } \\
\text { (Excellent, } \\
\text { Very Good, } \\
\text { Average) }\end{array}$} & \multirow{2}{*}{$\begin{array}{l}\text { Stay } \\
\text { (months } \\
\text { and } \\
\text { years) }\end{array}$} & \multirow{2}{*}{$\begin{array}{c}\text { Types Of } \\
\text { Travelers (Family, } \\
\text { Couples, } \\
\text { Individuals, } \\
\text { Business, Friends) }\end{array}$} & \multicolumn{5}{|c|}{ Comments } \\
\hline & & & & Product & Price & Environment & Process & Participants \\
\hline Glein S & Average & $\begin{array}{l}\text { December } \\
2016\end{array}$ & Family & $\mathrm{V}$ & & V & & \\
\hline $\begin{array}{l}\text { AtySilia (Ternate, } \\
\text { Indonesia) }\end{array}$ & Very good & $\begin{array}{l}\text { January } \\
2017\end{array}$ & Friend & V & & V & V & \\
\hline $\begin{array}{l}\text { Torben A } \\
\text { (Copenhagen, } \\
\text { Denmark) }\end{array}$ & Very good & $\begin{array}{l}\text { March } \\
2016\end{array}$ & Couples & V & & V & V & V \\
\hline Ulfulf & Very good & $\begin{array}{l}\text { March } \\
2016\end{array}$ & Alone & V & V & V & V & \\
\hline $\begin{array}{l}\text { Michael G (Bendigo, } \\
\text { Australia) }\end{array}$ & Very good & $\begin{array}{l}\text { August } \\
2015\end{array}$ & Couples & & & V & & V \\
\hline $\begin{array}{l}\text { Aisha H (Pekanbaru, } \\
\text { Indonesia) }\end{array}$ & Very good & April 2015 & Family & V & & V & V & V \\
\hline $\begin{array}{l}\text { Cheryljxx (Hobart, } \\
\text { Australia) }\end{array}$ & Very good & $\begin{array}{l}\text { Octoberr } \\
2014\end{array}$ & Family & V & & V & V & V \\
\hline Claudia M & Incredible & $\begin{array}{l}\text { December } \\
2015\end{array}$ & Couples & V & V & V & V & \\
\hline TristanP83 & Incredible & July 2016 & Couples & V & V & V & V & V \\
\hline Vidia K & Incredible & $\begin{array}{l}\text { March } \\
2016\end{array}$ & Friend & V & & V & V & V \\
\hline $\begin{array}{l}\text { Artika_Suri (Jakarta, } \\
\text { Indonesia) }\end{array}$ & Incredible & $\begin{array}{l}\text { December } \\
2015\end{array}$ & Friend & V & & V & V & V \\
\hline
\end{tabular}


"We pioneered this cottage business since 2016 and until 2017 is still under construction. The concept we use is eco-friendly tourism or environment-based tourism. It can be seen from the materials or materials that we use mostly from Meti Island such as bamboo, wood, and roof. We tried to build an eco-friendly cottage, so the building materials such as the marble we had removed and used it to build this seat (while pointing to the seats that have been made). We involve the local community as a workforce to complete the construction of the cottages, in the future, we will provide a place of business for the local people next to it (pointing to the location) so that the people of Meti can feel the impact of tourism development. I am currently working to coordinate with the village government and the people of Meti and work to increase awareness related to the environment. Before I came here, the coral reefs have been destroyed by fishing activities using bombs so that small fish or base fish are rarely seen nearby. Since then, I have attempted to ban fishing activities around this place for a while so that the fish can return and can be seen by tourists. We also stipulate a regulation that plastic garbage underneath by tourists from Mawea or Tobelo should not be disposed of here, because there is no final disposal here, so we affirm that tourists take it back to Mawea. In addition, we also coordinate with people who provide sea transportation services (ketinting) to the Meti Island, so as not to monopolize the price of sea transportation services to this place. We have coordinated with the village government and the sea transportation service provider (ketinting) so that the number of tourists above five people is given the price IDR 10,000 / per person (roundtrip), if less than five people then the price IDR.20.000 / per person (round-trip). Currently, there are no more people or people who catch fish using bombs around here, we are always watching and will immediately report to the authorities if there are elements who are still doing these crimes. In addition, I also observed many relics of the second world war on Meti Island that is not there, I hope the future local governments can pay attention to it with the existence of the policy of preservation of heritage objects ".

Kupa-Kupa Beach Cottage and Meti Beach Cottage managers do not always obtain the support of local communities. However, people who enjoy the benefits of Kupa-Kupa Beach cottages and Meti Beach Cottage will support and vice versa. As well as the results of observation and discussions with the marine transportation service providers reluctant unnamed states that:

"Kupa-Kupa Beach Cottage and Meti Beach Cottage business activities do not always get local support. For people who benefit economically from business activities tend to provide support. However, people who do not benefit from the business activities of Kupa-Kupa Beach Cottage and Meti Beach Cottage show negative perceptions and even resistance."

Thus it can be seen that the development of tourism through the concept of community-based ecotourism are able to provide economic, social and environmental benefits. The presence of Kupa-Kupa Beach Cottage and Meti Beach Cottage are able to provide economic benefits through the availability of employment opportunities which is able to increase local community welfare.

\section{Private Sector Involvement in Regional Tourism Development of North Halmahera District}

Space for the private sector in regional tourism is beneficial in the effectiveness and efficiency of tourism development. Indirectly, Meti Beach Cottage managers have become a liaison between North Halmahera Regency and Morotai Island Regency through tourism product provided. As well as Kupa-Kupa Beach Cottage manager who is the liaison between North Halmahera Regency and Bali Island through their products. Through the involvement of the private sector in regional tourism development of North Halmahera District, can be seen the existence of mutually beneficial relations.

The adoption of the concept of ecotourism is able to maintain environmental sustainability as the main tourist attraction. This paper shows that the concept of ecotourism adopted by Kupa-Kupa Beach Cottage and Meti Beach Cottage managers not only provides ecological benefits for environmental sustainability but also provides economic and social benefits. Both use building materials in accordance with the characteristics of local culture, cleaning and arranging the cottage environment so as to provide a sense of security and comfort for tourists, and in cooperation with local government and authorities in overseeing the waters of Kupa-Kupa Bay and Meti Island from fishing activities using homemade bombs. Prior research is linked to ecotourism development, emphasizing the government's role in mobilizing tourism development and enhancing local community participation [30].

The collaboration between private, public and university sectors in triple helix partnership is also 
essential in the implementation of ecotourism development concept [31]. In the context of KupaKupa Bay and Meti Island, the partnership formed between cottage entrepreneurs and village government and local communities is limited to the coordination of tariffs for sea transportation services, indicating an effort to collaborate in achieving the objectives. Similarly, a collaboration between the private and public sectors is a strategy for achieving tourism development goals, it affects destination governance [32]. Thus it can be seen that the partnership becomes a very essential thing in an effort to achieve the goal of tourism development.

Meti Beach Cottage is still in development stage so the local community involvement still limited. Efforts to involve the community in the development of tourism on Meti Island is still limited in coordination to set the price on sea transportation services from Mawea Village to Meti Island. Unlike the case with Kupa-Kupa Beach Cottage which has empowered the community by providing business locations for local communities and employing local communities in the management of Kupa-Kupa Beach Cottage. This shows that the growing cottage business the higher opportunity to empower the community. Involving local communities in cottages shows the responsibility of the tourism industry to the local economy and social conditions [13,33].

Through empowerment, the capacity of local communities in tourism can be improved [19]. In a certain period of time, it can affect the livelihoods or livelihoods of local people from the agrarian sector to the service sector [34]. This suggests that the private sector has a very essential role as a stimulus for community-based tourism development. Thus it can be seen that the development of ecotourism in the development of attractions Kupa-Kupa Bay with Meti Island is dominated by the private sector. The government will act as a stimulus and catalyst that is synergistic with the needs of the private sector to provide tourism facilities according to tourists' preference.

\section{CONCLUSION}

This paper shows that private sector tends to adopt community based ecotourism concept to achieve environment sustainability and tourism sustainability itself. The government will act as a stimulus and catalyst that is synergistic with the needs of the private sector to provide tourism facilities according to tourists' preference. KupaKupa Beach Cottage and Meti Beach Cottage managers seeks to provide employment for local communities as part of a marketing strategy so that they are mutually beneficial.

\section{REFERENCES}

[1] Case, R., T. Dey, J. Lu, J. Phang and A. Schwanz. 2013. Participant spending at sporting events: an examination of survey methodologies. Journal of Convention and Event Tourism 14(1), 21-41.

[2] Li, S. and L. Jago. 2013. Evaluating economic impacts of major sports events - a meta analysis of the key trends. Current Issues in Tourism 16(6), 591-611.

[3] Saayman, M., P. Van der Merwe, A. Saayman and M. E. Mouton. 2009. The socioeconomic impact of an urban park: The case of wilderness national park. Journal of Policy Research in Tourism, Leisure and Events 1(3), 247-264.

[4] Singgalen, Y., G. Sasongko and P. Wiloso. 2018. Tourism destination in remote area: problems and challenges of tourism development in North Halmahera as remote and border areas of Indonesia-Philippines. Journal of Indonesian Tourism and Development Studies 6(3), 175-186.

[5] Martina, S. 2014. Dampak pengelolaan taman wisata alam kawah putih terhadap kehidupan sosial dan ekonomi masyarakat. Jurnal Pariwisata I(2), 81-89.

[6] Puczkó, L. And T. Rátz. 2011. Social tourism in Hungary: From trade unions to cinema tickets. Current Issues in Tourism 14(5), 459473.

[7] Holden, A. 2000. Environment and tourism. London and New York. Routledge.

[8] Amuquandoh, F. E. 2010. Residents' perceptions of the environmental impacts of tourism in the Lake Bosomtwe Basin, Ghana. Journal of Sustainable Tourism 18(2), 223238.

[9] Wan, Y. K. P. 2012. The social, economic and environmental impacts of casino gaming in Macao: The community leader perspective. Journal of Sustainable Tourism 20(5), 737755.

[10] Alonso, A. D. and Y. Liu. 2013. Local community, volunteering and tourism development: the case of the Blackwood River Valley, Western Australia. Current Issues in Tourism 16(1), 47-62.

[11] Gurung, D. B. and R. W. Scholz. 2008. Community-based ecotourism in Bhutan: Expert evaluation of stakeholder-based scenarios. International Journal of 
Sustainable Development and World Ecology 15(5), 397-411.

[12] Nault, S. and P. Stapleton, 2011. The community participation process in ecotourism development: A case study of the community of Sogoog, Bayan-Ulgii, Mongolia. Journal of Sustainable Tourism 19(6), 695-712.

[13] Chettiparamb, A. and J. Kokkranikal, 2012. Responsible tourism and sustainability: The case of Kumarakom in Kerala, India. Journal of Policy Research in Tourism, Leisure and Events 4(3), 302-326.

[14] Satria, D. 2009. Strategi pengembangan ekowisata berbasis ekonomi lokal dalam rangka program pengentasan kemiskinan di wilayah Kabupaten Malang. Journal of Indonesian Applied Economics 3(1), 37-47.

[15] Pulungan, M. S. 2013. Optimalisasi pengembangan potensi ekowisata sebagai objek wisata andalan di Kabupaten Kutai Kartanegara Provinsi Kaltim. Jurnal Bina Praja 5(3), 205-214.

[16] Darcy, S. and S. Wearing. 2009. Publicprivate partnerships and contested cultural heritage tourism in national parks: A case study of the stakeholder views of the north head quarantine station (Sydney, Australia). Journal of Heritage Tourism 4(3), 181-199.

[17] Alfira, R. 2014. Identifiakasi Potensi dan strategi pengembangan ekowisata mangrove pada Kawasan Suaka Margasatwa Mampie di Kecamatan Wonomulyo Kabupaten Polewali Mandar. Hassanudin University. Makassar.

[18] Darmawati, D. M. 2005. Environmental marketing pada ekowisata pesisir untuk menggerakkan ekonomi rakyat di era otonomi daerah. Jurnal IImiah Pariwisata STP Pariwisata 10(2), 169-184.

[19] Hijriati, E. and R. Mardiana. 2015. Pengaruh ekowisata berbasis masyarakat terhadap perubahan kondisi ekologi, sosial dan ekonomi di Kampung Batusuhunan, Sukabumi. Sodality: Jurnal Sosiologi Pedesaan 2(3), 146-159.

[20] Prakoso, V. 2008. Kajian Sumberdaya ekowisata bahari di Pulau Sebesi, Desa Tejang, Kecamatan Rajabasa, Kabupaten Lampung Selatan. Bogor Agricultural University. Bogor.

[21] Singgalen, Y. and E. Kudubun, 2017. Partisipasi Masyarakat dalam pembangunan pariwisata (Studi kasus Kelompok Museum Pemerhati Sejarah Perang Dunia ke II di
Kabupaten Pulau Morotai). Journal of Social Research: Cakrawala 6(6),199-228.

[22] Onthoni, J., D. Simbolon and D. Jusadi, 2011. Analisis Penggunaan bom dalam penangkapan ikan di Kecamatan Kao Utara Kabupaten Halmahera Utara. Bogor.

[23] Danius, E. 2012. Hubungan Kristen - Islam pasca konflik. Uniera 1(1), 1-12.

[24] Pontoh, O. 2011. Penangkapan Ikan dengan bom di daerah terumbu karang Desa Arakan dan Wawontulap. Jurnal Perikanan Dan Kelautan Tropis 7(1), 56-59.

[25] Uar, N., S. Murti and S. Hadisusanto. 2016. Kerusakan Lingkungan akibat aktivitas manusia pada ekosistem terumbu karang. Majalah Geografi Indonesia 30(1), 88-95.

[26] Tain, A. 2011. Penyebab kemiskinan rumah tangga nelayan di wilayah tangkap lebih jawa timur. Humanity $7(1), 1-10$.

[27] Singgalen, Y., P. Wiloso, G. Sasongko. 2017. Evaluation of the Implementation of tourism policy. Jurnal Kebijakan \& Administrasi Publik 21(1), 82-106.

[28] Singgalen, Y. 2016. Persepsi, modal sosial, dan kekuasaan aktor dalam perumusan dan implementasi kebijakan pariwisata. Jurnal Pax Humana 3(2), 81-104.

[29] Almeida, M. 2011. The development of social tourism in Brazil. Current Issues in Tourism 14(5), 483-489.

[30] Rahajeng, A. 2016. The role of Kulon Progo regional government in developing nature based tourism. Jurnal Kebijakan \& Administrasi Publik 20, 49-62.

[31] Fathin, C. A., A. Achidsti and D. I. Priambodo. 2016. Analysis of Three actors: roles of government, private sector, and university toward Startup growth in Yogyakarta. Jurnal Kebijakan Dan Administrasi Publik 20(1), 3855.

[32] Dredge, D. and M. Whitford. 2011. Event tourism governance and the public sphere. Journal of Sustainable Tourism 19(4-5), 479499.

[33] Coles, T., E. Fenclova and C. Dinan. 2014. ColDRorate social responsibility reporting among European low-fares airlines: challenges for the examination and development of sustainable mobilities. Journal of Sustainable Tourism 22(1), 69-88.

[34] Singgalen, Y. and T. Prabawa. 2015. Bisnis seni kerajinan perak di Celuk: pemanfaatan modal dalam dinamika berwirausaha. Jurnal Interdisiplin Kritis 25(1), 71-96. 